\title{
Thrombolysis in Myocardial Infarction Flow-0
}

National Cancer Institute

\section{Source}

National Cancer Institute. Thrombolysis in Myocardial Infarction Flow-0. NCI Thesaurus.

Code C100040.

No perfusion: No antegrade flow beyond the point of occlusion. (www.TIMI.org accessed 21SEP2011) (ACC) 